\title{
CORRESPONDENCE
}

\author{
Role of the hospital in primary \\ paediatric care \\ A J R Waterston, MRCP; R J Brereton, \\ FRCS . \\ Radiation and growth hormone \\ deficiency \\ S M Shalet, MRCP, and others....... 1021 \\ Danger of salt as an emetic \\ W O Robertson, MD............ 1022 \\ Cimetidine and gastric carcinoma \\ R S Arnot, FRCSED. . \\ Perforation of peptic ulcer after with- \\ drawal of cimetidine \\ P V Turkie, MRCP; B D Keighley, MB ... . 1022 \\ Cimetidine and gastric ulcer healing \\ R J Machell, MRCP, and others. . . \\ MRC treatment trial for mild \\ hypertension \\ W S Peart, FRCP, FRS, and W E Miall, MD. \\ Care of the elderly sick \\ J G Evans, FRCP. \\ Joint appointments in general and \\ geriatric medicine \\ J C Brocklehurst, FRCSED, and others.... 1023 \\ Names of drugs \\ G D J Ball, MB; J W Maltby, FRCS; E T \\ Mathews, FFARCS. . . . . . . . . . 1024 \\ The drug bill \\ J F Lowe, FRCGP \\ Oestrogen treatment and endometrial \\ carcinoma \\ J Guillebaud, MRCOG. \\ Exercise-induced asthma \\ J P R Hartley, MRCP, and others; Elizabeth \\ $R$ Miller, $M B$. \\ Experimental trial of the tri-cycle pill \\ Elizabeth $M$ Elliott, MB; Nancy B Loudon, \\ MB, and R V Short, FRS, SCD . . . . . . . 1025 \\ Painless thyroiditis \\ G A MacGregor, MD . . . . . . . . . 1026 \\ The perilous skateboard \\ A R Rogers, MB. \\ Late infection after total hip replacement \\ W J Fincham, FIMLS, and Josephine Cook, \\ PHD . . . . . . . . . . . . . . . 1026 \\ Coeliac disease and malignancy \\ Irene $M$ Evans, MRCP............ 1026 \\ 1023 Effects of ethanol-induced hypoglycaemia \\ C Miquel, MD, and J Rubiés-Prat, MD . . . 1027 \\ 1023 1-x-Hydroxycholecalciferol for renal \\ osteodystrophy \\ R Ahmad, MB, and Beryl Large, SRN . ..... \\ Return to work

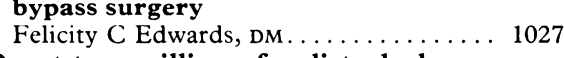 \\ Depot tranquillisers for disturbed \\ behaviour \\ M F Green, MRCP. \\ Correspondents are urged to write briefly so that readers may be offered as wide \\ a selection of letters as possible. So many are being received that the omission \\ of some is inevitable. Letters should be signed personally by all their authors.
}

Bruising in thyrotoxicosis

J A Thomson, FRCP................ 1027

Complications of transvenous

(transjugular) liver biopsy

D Lebrec, MD, and others.......... 1027

SI units and acidity

M Hamilton, FRCPSYCH. . . . . . . . . . . . 1028

Modified jejunoileal bypass for obesity

A Cuschieri, fRCS................ 1028

Oxytocin induction and neonatal

hyperbilirubinaemia

S Singhi, MD, and M Singh, MD ....... 1028

Acceptable and unacceptable risks

E M Glaser, MrCP............... 1028

Prevention of retained throat pack

B S Crawford, FRCS..................

Ulceration of face associa
trigeminal neuropathy

A G Freeman, FRCP. . .

Study of doctors' career decision

Rosemary Hutt, MA............... 1029

Obdurate politics

C M Fletcher, FRCP............. 1030

Attachment of community nurses to

general practice

J F Fisher, FRCGP. . . . . . . . . . . 1030

Ethics and etiquette of doctor-managers

J M Potter, fRCS................. 1030

Training for general practice

Anne L Gruneberg, FFARCS.......... 1030

\section{Role of the hospital in primary paediatric care}

SIR,-On a number of points Dr G M Komrower (24 September, p 787) paraphrases the Court Report ${ }^{1}$ in his comments on the role of the general practitioner, the child health practitioner, and the child health visitor; but I fear that his suggestion of a casualty-based primary care service would contribute little to solving the real problems he discusses.

Such a system would almost certainly markedly increase the hospital admission rate since no ill child presenting at the door could realistically be returned home, where no care would be available. It would also be hard to ensure continuing support for those families who most need it after the acute episode. Junior paediatric staff encountering a problem family for the first time would be unlikely to make a significant contribution to their welfare. The inclusion of what sound like general practitioner paediatricians in the scheme is interesting: surely they should be treating their own patients in the community and trying to raise the standards there rather than earning large extra sums from casualty sessions.

Experience from Sheffield and Gateshead ${ }^{2}$ shows that home-based schemes involving increased health visitor and nursing supervision of "problem" families can make a real impression on mortality and morbidity, as well as making economic sense. Surely we should be pushing such ideas with their educational potential rather than reverting to the "disease palace" for the cure of all ills.

TONY WATERSTON

Department of Child Health,

Committee on Child Health Services, Fit for the ${ }^{2}$ Hally, M R, et al, British Medical fournal, 1977, 1, 762.

SIR,-The parents of a child born with spina bifida or with Down's syndrome may preven another pregnancy by contraception and the pregnant mother of such a child may elect to have an affected fetus aborted. Antenatal supervision and investigation and intensive care after delivery may allow a considerable reduction in the damage to the baby during the perinatal period.

However, would Dr G M Komrower (24 September, $p$ 787) enlighten me as to how improved antenatal supervision and intensive care after delivery with reduction in damage to the baby in the perinatal period can result in a reduction in the number of children in the community suffering from such disorders as Down's syndrome or spina bifida, as implied in his section on "Children at risk" ?

\section{R J BRERETON} Alder Hey Children's Hospital,
Liverpool
Ninewells Hospital, Dundee

\section{Radiation and growth hormone deficiency}

SIR,-We were disappointed in your leading article on this subject (27 August, p 536).

Firstly, you state that "lack of any dosedependent relationship weakens the case against radiation." This "lack" was corrected in 1976 when we analysed the relationship between the radiation dose delivered to the hypothalamic-pituitary region and the peak growth hormone $(\mathrm{GH})$ response to insulin hypoglycaemia in 39 children irradiated for brain tumours anatomically distant from the hypothalamic-pituitary axis and 17 children with acute leukaemia who received prophylactic central nervous system irradiation. ${ }^{1}$ There was a significant inverse correlation between the radiation dose and the peak $\mathrm{GH}$ response $(r=-0.39 ; P=0.002)$. Thirty-six out of the 41 patients who received a radiation dose greater than 2900 rads showed an impaired $\mathrm{GH}$ response.

The second point concerns the comment that "the normal gland is unlikely to be affected by quite high doses of radiation (5-6000 rads), as used, for example, for treating carcinoma of the nasopharynx." Samaan et al studied hypothalamic-pituitary function in 15 patients who received irradiation to that area (dose range 5000-8300 rads) during treatment of carcinoma of the nasopharynx. Twelve patients had evidence of hypothalamic dysfunction. Eleven showed impaired $\mathrm{GH}$ responses and six impaired cortisol responses to insulin hypoglycaemia. All 12 had an elevated serum prolactin concentration with no rise after chlorpromazine. Three patients showed subnormal thyroid function in the presence of a normal but delayed rise of serum thyroidstimulating hormone (TSH) after thyro- 